\title{
The Tourist Model in the Collaborative Economy: A Modern Approach
}

\author{
Giuseppe Russo $^{1}$, Rosa Lombardi ${ }^{1} \&$ Sebastiano Mangiagli ${ }^{1}$ \\ ${ }^{1}$ University of Cassino and Southern Lazio, Italy \\ Correspondence: Rosa Lombardi, Department of Economics and Law, University of Cassino and Southern \\ Lazio, Via S. Angelo Loc. Folcara, Cassino, Italy. E-mail: rosa.lombardi@unicas.it
}

Received: Jaunary 15, 2013

Accepted: February 5, 2013

Online Published: March 14, 2013

doi:10.5539/ijbm.v8n7p1

URL: http://dx.doi.org/10.5539/ijbm.v8n7p1

\begin{abstract}
Tourism is a complex and transversal phenomenon of huge social-economic importance that in the last few years has entered the phase of globalization and internationalisation. Furthermore, by virtue of the considerable reinforcement of means of communication, the diffusion of tourism has undergone an unprecedented acceleration and therefore the means of sourcing of information and opportunities of consumption have become numerous. In this direction, distributed hospitality needs investigated, considering that, at the current status, it is not fully understood in terms of inborn potentials by the local policy makers. In general, distributed hospitality represents a form of hospitality that is based on relations of a collaborative nature, especially suitable to generate virtual requalification processes on the territory of residential assets, of repositioning of the tourist destination, as well as reinforcing the attractiveness of the area. Moreover, even though different kinds of inter-company relations exist, the aggregation phenomenon appears to be the answer to the cognitive requirements and the means to activate a modern differential process on the market. The theme of sustainability of tourism development will therefore be faced through the identification of current forms of experience of diffused hotels that exist on an Italian level; subsequently, changing from some morphological indicators deducted by the Network Analysis, a model was proposed in the attempt to define the governance model of diffused hotels. So, the research question is the following: can the formula of distributed hospitality lead to enhancement of a tourist destination with a view to sustainability?
\end{abstract}

Keywords: collaborative economy, tourism, distributed hospitality, sustainability governance, NDH

\section{Introduction and Research Question}

Tourism is a complex and transversal phenomenon of huge social-economic importance (Hussein Alhroot, 2012; Taleghani, Sharifi \& Mousavian, 2011) that in the last few years has entered the phase of globalization and internationalisation (Pechlaner, Pichler, \& Volgger, 2012). If, up until just a few years ago, it represented a marginal aspect of the life of a country and it was believed that it was capable of reproducing itself naturally without the need for any structural plan and specific intervention, it is now considered as a strategic activity, able to provide a concrete answer to the request for economic development of the territory (Rispoli \& Brunetti, 2009).

Furthermore, by virtue of the considerable reinforcement of means of communication (Kokash, 2012), the diffusion of tourism has undergone an unprecedented acceleration and therefore the means of sourcing of information and opportunities of consumption have become numerous (Pencarelli \& Migliaccio, 2011).

In the same way, the numerous amount of demands and forms of behaviour that characterize the demand for tourism are stimulating the development of a much broader and more articulated range of offers. In fact, tourists are currently searching for opportunities that allow them to come into contact with new cultures in an experience based on authenticity and sustainability, without sacrificing the conveniences that they are used to: modern travellers are replacing more and more traditional tourists who enjoy staying in locations that they are familiar with or famous destinations, in the search for holidays that are full of experience (Aziz \& Ariffin, 2009).

Among these new tourist offers, the formula of distributed hospitality deserves being investigated into, considering that, at the current status, it is not fully understood in terms of inborn potentials by the local policy makers. 
In general, distributed hospitality represents a form of hospitality that is based on relations of a collaborative nature (Himmelman, 2001; Ricciardi, 2010; Porter, 1998), especially suitable to generate virtual requalification processes on the territory of residential assets, of repositioning of the tourist destination, as well as reinforcing the attractiveness of the area. Moreover, even though different kinds of inter-company relations exist (Giaccari, 2003; Grandori, 1995; Normann \& Ramirez, 1995; Rullani, 1993), the aggregation phenomenon appears to be the answer to the cognitive requirements and the means to activate a modern differential process on the market.

The theme of sustainability of tourism development will therefore be faced through the identification of current forms of experience of diffused hotels that exist on an Italian level; subsequently, changing from some morphological indicators deducted by the Network Analysis (Carrington, Scott, \& Wasserman, 2005; Carley, 2003), a model was proposed in the attempt to define the governance model of diffused hotels.

In consideration of the above, the research question of this contribution is the following: can the formula of distributed hospitality lead to enhancement of a tourist destination with a view to sustainability?

\section{Sustainability of Tourist Development and the Formula of Distributed Hospitality: An Analysis of Literature}

According to part of the literature related to tourism (Bieger, 1996; Bieger, 1998; Flagestad \& Hope, 2001; Bonetti, Petrillo, \& Simoni, 2006; Bellagamba, Brunetti, Pencarelli, \& Vigolo, 2007; Minguzzi \& Presenza, 2010; Franch, 2010; Pechlaner, Paniccia, Valeri, \& Raich, 2012; Mazanec, Wöber, \& Zins, 2007; Paniccia, Silvestrelli, \& Valeri, 2010; Martini, 2005; Keller \& Bieger, 2008), this phenomenon is configured as a tourist destination or "as a complex system of offer consisting of the resources available (general and specific) and the tourist services offered in a territory" (Cantone, Risitano, \& Testa, 2007, p. 21).

The need to follow an approach oriented towards sustainability by the tourist destinations "originates from the impact of consistent changes in the global context, in terms of tourist demand and offer that in order to be governed in a managerial key need adequate instruments and approaches" (Franch, Martini, \& Della Lucia, 2011, p. 2).

Sustainability does, in fact, represent a key factor for re-generation of the tourist offer. In other words: "In order for tourism to be successful, it must be sustainable. In order to be sustainable, it must be carefully planned and handled" (Godfrey \& Clark, 2002, p. 20). Furthermore, with reference to the lifecycle of a tourist destination: “(....) we can consider that by applying the principles of sustainability, the lifecycle itself should be modified by extending and moving it in terms of time" (Confalonieri, 2008, p. 26).

From a historical point of view, the first definition of sustainable development has been formalized in the Brundtland Report (Varanini, 2011) in 1987, for which development is sustainable if “(....) it satisfies the requirements of the present without compromising the possibility of future generations in satisfying its own personal needs" (World Commission on Environment and Development, 1987).

One year after the International Tourism Organisation extended the concept to tourism, defining tourist development capable of satisfying the demands of today's tourists and of the relative welcoming regions, allowing for an increasing the opportunities for the future as sustainable (Cater \& Lowman, 1994; Perkins \& Brown, 2012; Fiorello \& Bo, 2012; Saayman, Rossouw, \& Saayman, 2012; Baral, Stern \& Hammett, 2012; Jamrozy, 2007; Nicely \& Palakurthi, 2012; Shikida, Yoda, Kino, \& Morishige, 2010; Kennett-Hensel, Sneath, \& Hensel, 2010; Zeppel, 2010; Moscardo, 2008; Billington, Carter, \& Kayamba, 2008; Giannoni, 2009; Benevolo, 2011; Pencarelli \& Splendiani, 2010; Ritchie \& Crouch, 2000; Ruozi, 2005). "Therefore, sustainable tourist development attempts to balance out the economic repercussions of tourism with the preservation of the irreproducible resources involved in the production of tourism, the environment and the culture of local communities in primis. This balance is the presupposition for a long-term competitive advantage of the destinations in terms of the attractiveness of flows of visitors and the characteristics of the offer compared with competitors, as well as the quality of the tourist experience and the life of residents" (Franch, Martini, \& Della Lucia, 2011, p. 2).

This means that tourist destinations should be able to formulate strategies that take into consideration the existing relationship between sustainability, social responsibility of the company (Matacena, 1984; Coda, 1985; Lee, Fairhurst, \& Wesley, 2009; Holcomb, Upchurch, \& Okumus, 2007; Cafferata, 2009a; Sciarelli, 2007; Schillaci \& Longo, 2010; Tonini, 2010), competitiveness and management. Therefore, for purposes related to tourist development, a careful development policy based on sustainability, focusing on the emerging segments of the market (Weaver, 2000) is necessary and, unlike mass tourism, undertakes ethical behaviour (Caselli, 2003) when on the holiday (Martin \& Woodside, 2008; Barbieri \& Mahoney, 2010; Tasci \& Boylu, 2010; Saraithong 
\& Chancharoenchai, 2011; Mohajerani \& Miremadi, 2012).

Important authors have sustained that diffused hotels can "represent a truly appropriate example of how to enhance a territory-destination with a view to sustainability, contributing towards maintaining environmental, social and economic balance" (Paniccia, 2012, pages 12-13). A diffused hotel is basically a "hotel that is not built", "horizontal, sustainable, an attraction for the town centres and districts of our country" (Dall'Ara, 2010, p. 7).

The first form of a diffused hotel was born in Carnia, in the region of Friuli Venezia Giulia, following the earthquake of 1976, with the objective of recovering rural property in small mountain districts characterised by a constant phenomenon of emigration and poor economic dynamism (Battaglia, 2007).

It is a modern form of experience (Pine II \& Gilmore, 1999; Carù \& Cova, 2003; Cafferata \& Cherubini, 2008; Resciniti, 2004; Resciniti \& Maggiore, 2009; Pencarelli \& Splendiani, 2008; Paniccia, Minguzzi, \& Valeri, 2011; Dall'Ara, 2010) (Tidd, Bessant, \& Pavitt, 1997) by virtue of the horizontal diffusion of the rooms; it is in fact possible for all guests booked into the various rooms distributed within the territory and close to them to use the hotel services (Dall'Ara \& Esposto, 2005). Generally, the buildings of distributed hospitality are inserted within a context of historical-cultural interest; furthermore, the area in which distributed hospitality rises has a small amount of inhabitants, therefore allowing guests to create relations with residents.

In other words, distributed hospitality is characterised by the fact that it has two halls, one inside and one outside of the hotel: "(...) the corridors of distributed hospitality should be the roads; an external hall should be added to the traditional hall, the neighbourhood" (Dall'Ara, 2010, p. 8).

Presuming inclusion in the network of existing houses, this is a kind of horizontal hotel that is characterised by a whole range of requirements (Dall'Ara, 2010):

- Management in an entrepreneurial manner;

- Offer of hospitality and restaurant services;

- Living units located in several separate and existing buildings;

- Common services: the presence of premises set out for common areas for guests is necessary (hospitality, bar, restaurants);

- A distance of no more than 200 or 300 metres between the living units and the structure with the main hospitality services;

- The presence of a welcoming community that favours integration in the territory;

- The presence of an authentic environment, easy to associate with the social reality and local culture;

- The creation of a kind of "symbiotic relationship" (Paniccia, 2012, p. 14) among the homes and the areas in question (Cafferata, 2009b);

Constitution through a private initiative (an entrepreneur or a group of entrepreneurs) or originating from a coalition of public and private actors on the territory (local public authorities such as municipalities, provinces, regions, entrepreneurial associations, cultural and social authorities) (Confalonieri, 2011, p. 276).

\section{The Empirical Control: Method of Investigation}

The empirical observation that is proposed is focused on the current state of development of diffused hotels in Italy. The decision was made to limit our field of investigation to Italy only because in the current condition the only experience of a diffused hotel abroad can be found in Spain (since 2012).

An example of a hotel form similar to a diffused hotel (but with characteristics that are sometimes drastically different compared with the Italian feature) already exists in Switzerland and in Croatia; here, however, in the current condition legislation does not recognize such form of hospitality. In the same way, on an international level academic interest for diffused hotels has increased (Dropulić, Krajnović, \& Ružić, 2008; Grzinic \& Saftic, 2012; Avram \& Zarrilli, 2012).

It must be pointed out that, dealing with a relatively new topic, an ad hoc framework legislation on a national level does not exist nor do statistic surveys related to the field of diffused hotels in the field of official statistics based on Italian hospitality system exist. Therefore, the survey method followed was that of the case study analysis, of a quality nature and with a view to multiple cases (Yin, 2009), focused on interaction with the individuals investigated into and the specific nature of the phenomenon analysed (Eisenhardt, 1989; Edmondson \& McManus, 2007). In this way an analysis of some company cases was carried out that, due to the notoriety 
achieved, have succeeded in asserting itself on national and international attention.

In particular, due to the elaboration of the study cases, identification of all of distributed hospitality units currently operating in Italy has been commenced, achieved by comparing the research motors of the National Association of Diffused Hotels, the Association of Authentic Districts of Italy and the Club of the Most Beautiful Districts of Italy, then moving on to consultation of articles originating from national economic magazines as well as academic publications on the topic in question.

\section{Results of the Analysis}

From the investigations carried out, it has emerged that out of the 57 diffused hotels in Italy the main category is that of hotels in historical districts with 34 structures, followed by hotels in rural ancient hamlets (16) and hotels in period buildings (7) (table 1). With regards to this aspect, it is interesting to see that out of the 212 historical districts that belong to the Club of the Most Beautiful Districts of Italy, only 5 include a diffused hotel; this circumstance highlights how these forms of hospitality in Italy can be diffused even more.

Table 1. Diffused hotels present in Italy during the 3rd quarter 2012

\begin{tabular}{|c|c|c|c|c|c|}
\hline \multirow[b]{2}{*}{ Region } & \multirow{2}{*}{$\begin{array}{c}N^{\circ} \text { diffused } \\
\text { hotels }\end{array}$} & \multicolumn{3}{|c|}{ Type } & \multirow[b]{2}{*}{ Average $n^{\circ}$ living units } \\
\hline & & $\begin{array}{c}\text { Historical } \\
\text { district }\end{array}$ & Period residence & Ancient rural hamlet & \\
\hline Emilia-Romagna & 3 & 1 & 1 & 1 & 4.3 \\
\hline Friuli Venezia Giulia & 3 & 0 & 0 & 3 & 21.3 \\
\hline Liguria & 2 & 2 & 0 & 0 & 7.0 \\
\hline Piemonte & 1 & 0 & 0 & 1 & 2.0 \\
\hline Northern Italy & 9 & 3 & 1 & 5 & 8.7 \\
\hline Lazio & 5 & 3 & 1 & 1 & 9.7 \\
\hline Marche & 6 & 2 & 1 & 3 & 6.0 \\
\hline Tuscany & 6 & 5 & 0 & 1 & 10.5 \\
\hline Umbria & 8 & 3 & 2 & 3 & 6.4 \\
\hline Central Italy & 25 & 13 & 4 & 8 & 8.2 \\
\hline Abruzzo & 2 & 2 & 0 & 0 & 15.5 \\
\hline Basilicata & 1 & 1 & 0 & 0 & 13.0 \\
\hline Campania & 1 & 0 & 1 & 0 & 4.0 \\
\hline Molise & 4 & 2 & 0 & 2 & 3.7 \\
\hline Puglia & 5 & 5 & 0 & 0 & 9.8 \\
\hline Sardinia & 6 & 4 & 1 & 1 & 2.3 \\
\hline Sicily & 4 & 4 & 0 & 0 & 4.7 \\
\hline Southern Italy and Islands & 23 & 18 & 2 & 3 & 7.6 \\
\hline Total Italy & 57 & 34 & 7 & 16 & 8.0 \\
\hline
\end{tabular}

Source: our elaboration.

Other observations can be deducted from an analysis of localization of distributed hospitality. The highest concentration is in Central Italy with 25 structures, only 8 of which are located in Umbria, a region with the highest number of units; the role played by the South and by the Islands with 23 hotels should not be neglected, while the North has only 9. In this regard, it is important to point out that, in general terms, the regions with the highest number of distributed hospitality centres are the ones that have regulated these realities before anybody else (the first four regions that have regulated the distributed hospitality centres are Sardinia with the Regional Law n. 27 of 12th August 1998, Friuli Venezia Giulia with the Regional Law n. 2 of 16th January 2002, the Marche region with the Regional Law n.9 of 11th July 2006 and the Umbria region with the Regional Law n.18 of 27th December 2006).

Once again it is important to see how the Abruzzo region, although it has the most famous and studied distributed hospitality in the world, the Sextantio (Avram \& Zarrilli, 2012; Silvestrelli, 2011; Paniccia, 2011; Paniccia, Minguzzi, \& Valeri, 2011; Paniccia, 2012; Valeri, 2011; Paniccia, Pechlaner, \& Valeri, 2007; Paniccia, Pechlaner, \& Valeri, 2010; Cavuta, 2007), has not yet organized a specific norm in this field.

According to the dimensions registered, it was acknowledged that in Italy the average number of living units that form distributed hospitality is 8 . In detail, the reasons for which higher values have been registered 
compared with the Italian average are Friuli Venezia Giulia (21.3), Abruzzo (15.5), Basilicata (13), Tuscany (10.5), Puglia (9-8) and Lazio (9.7).

From a constitutive point of view, the majority of Italian distributed hospitality units have been born due to private entrepreneurial initiatives by individuals strongly rooted with the territory that they belong to. This is the case of the Sextantio, located in the Santo Stefano district of Sessanio in Abruzzo, which has undergone renovation work in order to be used by visitors, or the Corte Fiorita in the Bosa district in the province of Oristano that has allowed for the restoration of private homes and public buildings of historical and architectural interest, leaving local traditions unchanged and, at the same time, revitalizing a centre that is undergoing constant abandonment due to depopulation connected with the search for areas that are much easier to reach and much more attractive from an economic point of view. Further examples of distributed hospitality consisting of private entrepreneurs are represented by La Piana dei Mulini, born from an ancient mill in the Municipality of Colle D'Anchise in the province of Campobasso, and the Muntaecara, created in the district of Apricale in the province of Imperia. Only in some cases has distributed hospitality been created from the impulse of a group of local actors; purely as an example, the experience of Smerillo in the Marche region and the Forgaria Monte Prat in the province of Udine are quoted (Mandelli \& La Rocca, 2006).

In the field of the tourist field of hospitality, the formula of distributed hospitality definitely represents one of the most modern forms (Rullani, Paiola, Sebastiani, Cantù, \& Montagnini, 2007; Chen, Chen, Ho, \& Lee, 2009) with regards to the solutions proposed. Among the most interesting initiatives generated by distributed hospitality, the following are highlighted: "distributed lunch" in the Val di Kam of S. Angelo Muxaro in the province of Agrigento; enhancement of the ultra-centenarian in a tourist key by Sardinian distribution hospitality centres; the "unique local dishes" of the Altopiano di Lauco in Friuli Venezia Giulia; the creation of accommodation that recall the medieval history of the hosting district by the already mentioned Sextantio. With specific reference to the Sextantio, the district was transformed into a cultural heritage location where the material dimension and the immaterial dimension of the cultural product are combined in a harmonious manner: the artistic assets, history and traditions on the one hand and culture, experience and expectations of the visitor/tourist on the other hand create a specific and personalized space of experience with marked multi-dimensional characteristics (Silvestrelli, 2011, p. 267).

Therefore a lot of innovation has been produced in Italy even if others should be introduced in order to generate dynamics of development in the area in which the hotel operates. For this purpose, it is believed that distributed hospitality, in the same way as the things that happen with tourist destinations, should be conceived in the same way as a virtual service network, therefore a reticular system (D'Alessio, 2008; Lomi, 1991; Kogut, 2000; Morita, James Flynn, \& Ochiai, 2011; Ricciardi, 2010; Porter, 1998; Levanti, 2010; Trequattrini, Russo, \& Lombardi, 2012a; Trequattrini, Russo, \& Lombardi, 2012b; Gulati, 1998; Håkansson \& Snehota, 1995; Trunfio, 2008) of tourist services, handled by a main operator who, on the one hand, stimulates and promotes territorial development as a "catalyst of development" (Schillaci \& Gatti, 2011, p. 30) and, on the other hand, creates the presuppositions for inter-organisational cooperation, defining the times and methods (Pechlaner, Reuter, \& Bachinger, 2010).

In brief, the study of Italian distributed hospitality shows that it is possible to enhance a tourist destination with regards to its artistic-cultural and environmental heritage as well as the mainly entrepreneurial aspects related to the generation of profit by the organizations operating within the territory. All of this depends on the abilities of the territorial decision makers in promoting and developing cultural orientation towards co-development between the territories, tourist companies operating in it, tourists and local communities, focusing the right amount of attention on the benefits generated (Paniccia, Minguzzi, \& Valeri, 2011).

\section{The Network Diffusion Hotel-NDH Model}

Research carried out, whose results should induce local policy makers to reflect on the potentials deriving from recourse to the formula of distributed hospitality, has highlighted the deficiency, on a managerial level, of specific models aimed at highlighting the governance system of this form of hospitality. In the same way, the "Network Diffusion Hotel- NDH" model is proposed, according to the representation shown below (table 2). 
Table 2. The "network diffusion hotel-NDH" model

\begin{tabular}{ll}
\hline \multicolumn{1}{c}{ Structure indicators } & \\
\hline $\begin{array}{l}\text { Number of NDH } \\
\text { Number of companies- entrepreneurs involved } \\
\text { Quantity of human capital involved } \\
\text { Level of territorial concentration } \\
\text { Number of NDH regulations } \\
\begin{array}{l}\text { Density of relations between companies and entrepreneurs involved } \\
\text { Turnover achieved in the centre }\end{array}\end{array}$ & IQ. 1 Proprietor situation of the NDH network \\
\hline
\end{tabular}

Source: our elaboration.

The first part of the model is based on some indicators of a structural nature, explanatory of the intrinsic characteristics of distributed hospitality:

- The number of NDH's consists of the quantity of distributed hospitality units present within one specific area;

- The number of companies-entrepreneurs involved is explicative of the number of companies and/or entrepreneurs that have created each single production unit and that deal with operating in the network through common activities;

- The quantity of human capital (Epifani, 2003; Flamholtz, 1986; Flamholtz, 1989; Lev \& Schwartz, 1971; Zanda, Lacchini, \& Oriccchio, 1993) provides the number of employees involved in carrying out their own network activities;

- The level of territorial concentration can be achieved by using the Gini or Herfindahl-Hirschman index of concentration;

- The number of NDH regulations indicates the number of acts aimed at regulating internal operation of the distributed hospitality units;

- For calculation of the density of relations between companies-entrepreneurs involved, reference can be made to some morphological indicators taken from the Network Analysis (Carrington, Scott, \& Wasserman, 2005; Carley, 2003; D’Alessio, 2008; Borgatti, Everett, \& Freeman, 2002): density, centrality, length, heterogeneity and connection. The indicator of density registers cohesion of the network through mutual and reiterated connections in time between the aggregated companies; centrality reveals the presence of a leader company or more than one company that guides the network; length measures the extension of territorial boundaries; heterogeneity summarises the number of companies (Bertini, 1990; Zanda, 2009) belonging to the network and classified together in a homogeneous manner; connection increases as the number of knots and/or arches that, leaving the network, create its fragmentation, reduce;

- The turnover achieved during the year is an indicator of an economic nature that expresses the turnover produced by the distributed hospitality units.

In the second part, however, the distributed hospitality units included in the study are compared with the Italian hospitality companies, from all of the aspects previously considered.

The third and last part includes three indicators of quality (IQ.1, IQ.2 and IQ.3) that are formed according to the opinions expressed by owners and/or managers (Jensen \& Meckling, 1976; Grossman \& Hart, 1988) through the presentation of a mini questionnaire (table 3 ).

Table 3. The mini questionnaire of the "Network Diffusion Hotel - NDH" model

\begin{tabular}{lllll}
\hline Indicator & Question & Range of points per question \\
\hline & According $\quad$ to $\quad$ the & 1 (property of one or few individuals involved actively in company \\
IQ. 1 Proprietor situation of & $\begin{array}{l}\text { governance and control management); } \\
\text { structure of the company, }\end{array}$ & 2 (shareholder majority owned by one shareholder who mainly has interests \\
the NDH network & to which of the following & of a financial nature (for example, private equity fund, bank)); \\
& categories should the & 3 (total ownership or control (more than 51\%) by another company (for \\
\hline
\end{tabular}


current proprietor situation be attributed? example, holding, belonging to a company group));

4 (company listed in the stock exchange with a stable control package)
1 hybrid governance (non defined governance);

IQ. 2 Level of participation in decisions by members of the NDH network

IQ. 3 Level of control of property (principal) on management (agent)
How many members of the $\mathrm{NDH}$ network take part in decisions?

In the case of separation between property and management, how many annual controls does property carry out with regards to the manager?
2 centred governance (just one member of the NDH network makes the decisions for the NDH network);

3 distributed governance (all members of the NDH network take part in the decisions)

1,2 (rare controls);

$>2$ e $<12$ (very few controls);

12 (monthly controls);

$>12$ e $\leq 24$ (frequent controls);

$>24$ (very frequent controls)

Source: our elaboration.

The answers assigned to each questionnaire can be analysed in general or for each single indicator. In the first hypothesis, in providing an opinion on the governance system of the distributed hospitality unit investigated, the three indicators can consist of several configurations according to the indications provided in table 4: when the points of IQ. 1, IQ. 2 and IQ. 3 are low, the distributed hospitality unit is characterised by not such an extensive governance; if these points are average, it is the case of an extended governance; if they are high, governance is very extended.

Table 4. The governance system according to the "network diffusion hotel - NDH" model

\begin{tabular}{ccc}
\hline Low & Points for IQ.1, IQ.2 and IQ.3 & Average \\
\hline Distributed hospitality with small governance & Distributed hospitality with extended & Distributed hospitality with very \\
extended governance & governance
\end{tabular}

Source: our elaboration.

This is an instrument of dynamic assessment as it can be compared with other future years or with results that have emerged from other distributed hospitality centres using the same model.

\section{Conclusions and Hints for Future Research}

From a study carried out in this field it has emerged that distributed hospitality represents a form of hospitality that has not been investigated into from a company governance point of view (Lacchini, 2002; Sheikh \& Chatterjee, 1995; Trequattrini, 1999).

The reality of Italian distributed hospitality units investigated also highlights how small companies (Cafferata, 2010), if correctly governed, can play a role in the process of economic, cultural and social growth of the territory. In order to achieve this result a careful plan of intervention on a training and organizational level should be carried out.

In this direction, it is important to focus on training aimed at providing knowledge, abilities and skills in a field of constant development such as tourism. The objective of training is to increase and improve knowledge, of the specific field and also of several transversal disciplines such as foreign languages, new technologies, communication, public relations and relations based on trust (Fukuyama, 1995; Luhmann, 2002).

Moreover, the challenge for the future of distributed hospitality can be based on the ability to sustain reticular development models (Barabasi, 2002; Bastia, 1989), in which tourism can act as a propulsive social and economic power. 
Therefore, regardless of the territorial planning process and the real availability of resources for the creation of projects, it is vital that local communities are able to diffuse, especially among the new generations, a greater inclination to innovation (Gollin, 2008) and be much more inclined to enhance local cultural traditions.

In conclusion, the cases of distributed hospitality units presented in this report show that for one tourist destination sustainability and the creation of value (Guatri, 1991; Turco, 2004) do not clash between them but form variables that are closely interconnected: on the one hand, enhancement of a destination in a tourist key may make a context sustainable from a social-economic and environmental profile; on the other hand, the achievement of sustainability creates value on a territorial value, to companies, to the local community and to tourists themselves. Subsequently this contribution can also be interpreted as the first level of a much broader investigation for our future research in this field.

\section{Acknowledgments}

This paper is the joint work of the three Authors: paragraphs 1 and 2 are by Giuseppe Russo, paragraphs 5 and 6 are by Rosa Lombardi and paragraphs 3 and 4 are by Sebastiano Mangiagli.

\section{References}

Airoldi, G., \& Forestieri, G. (1998). Corporate governance. Analisi e prospettive del caso italiano. Milan: Etas.

Avram, M., \& Zarrilli, L. (2012). The Italian Model of "Albergo Diffuso": a Possible Way to Preserve the Traditional Heritage and to Encourage the Sustainable Development of the Apuseni Nature Park. Journal of Tourism and Geo Sites, 9(1), 32-42.

Aziz, N. A., \& Ariffin, A. A. (2009). Identifying the Relationship between Travel Motivation and Lifestyles among Malaysian Pleasure Tourists and Its Marketing Implications. International Journal of Marketing Studies, 1(2), 96-106.

Barabasi, A. L. (2002). The New Science of Networks. Cambridge: Perseus Publishing.

Baral, N., Stern, M. J., \& Hammett, A. L. (2012). Developing a scale for evaluating ecotourism by visitors: a study in the Annapurna Conservation Area, Nepal. Journal of Sustainable Tourism, 20(7), 975-989. http://dx.doi.org/10.1080/09669582.2012.663379

Barbieri, C., \& Mahoney, M. (2010). Cultural Tourism Behaviour and Preferences among the Live-performing Arts Audience: an Application of the Univorous-Omnivorous Framework. International Journal of Tourism Research, 12, 481-496.

Bastia, P. (1989). Gli accordi tra imprese. Fondamenti Economici E Strumenti Informativi. Bologna: Clueb.

Battaglia, F. (2007). Turismo rurale: l'albergo diffuso per la conservazione del paesaggio. Il caso della Carnia. In Donato, C. (Eds.), Turismo rurale, agriturismo ed ecoturismo quali esperienze di un percorso sostenibile (pp. 108-122). Trieste: EUT.

Bellagamba, A., Brunetti, F., Pencarelli, T., \& Vigolo, V. (2007). La letteratura italiana ed internazionale sul destination management. In Sciarelli, S. (Eds.), Il management dei sistemi turistici locali: strategie e strumenti per la governance. Turin: Giappichelli.

Benevolo, C. (2011). Problematiche di sostenibilità nell'ambito del turismo nautico in Italia. Impresa Progetto.

Bertini, U. (1990). Il sistema d'azienda. Schema d'analisi. Turin: Giappichelli.

Bianchi, A. (1996). Corporate Governance. Considerazioni introduttive. Rivista delle Società, 2.

Bieger, T. (1996). Management von Destinationen und Tourismusorganisationen. Monaco: Oldenbourg Verlag.

Bieger, T. (1998). Reengineering destination marketing organizations. The case of Switzerland. The Tourist Review, 53(3).

Billington, R. D., Carter, N., \& Kayamba, L. (2008). The practical application of sustainable tourism development principles: A case study of creating innovative place-making tourism strategies. International Journal of Culture, Tourism and Hospitality Research, 8(1), 37-43. http://dx.doi.org/10.1057/thr.2008.4

Bonetti, E., Petrillo, C. S., \& Simoni, M. (2006). Tourism system dynamics: a multi-level destination approach. In Lazzeretti, L., \& Petrillo, C. S. (Eds.), Tourism Local Systems and Networking, Advances in Tourism Research Series. Oxford: Elsevier. http://dx.doi.org/10.1016/B978-0-08-044938-8.50012-3

Borgatti, S. P., Everett, M. G., \& Freeman, L. C. (2002). Ucinet for Windows software for Social Network analysis Version. Columbia: Analytic Technologies. 
Brunetti, F. (1999). Il turismo sulla via della qualità. Padua: Cedam.

Cafferata, R. (2009a). Il cantiere aperto della responsabilità sociale d'impresa. Impresa Progetto.

Cafferata, R. (2009b). Management in adattamento. Tra razionalità economica e imperfezione dei sistemi. Bologna: Il Mulino.

Cafferata, R. (2010). Competitive Advantage and Internationalization of Italian Small and Medium-Sized Manufacturing Firms. Department of Business Studies (DSI) Essays Series, 1.

Cafferata, R., \& Cherubini, S. (2008). Innovare nei servizi. Economia e Diritto del Terziario, special issue, 2.

Cantone, L., Risitano, M., \& Testa, P. (2007). Strategie di sviluppo delle destinazioni turistiche e ruolo della marca territoriale. Mercati e Competitività, 1.

Carley, K. M. (2003). Dynamic network analysis. In Breiger, R., Carley, K.M., \& Pattison, P. (eds.), Dynamic Social Network Modeling and Analysis (pp. 133-145). Workshop Summary and Papers. Washington: The National Academy Press.

Carrington, P. J., Scott, J., \& Wasserman, S. (2005). Models and methods in social network analysis. New York: Cambridge University Press. http://dx.doi.org/10.1017/CBO9780511811395

Carù, A., \& Cova, B. (2003). Esperienza di consumo e marketing esperienziale: radici diverse e convergenze possibili. Micro \& Macro Marketing, 12, 187-212.

Caselli, C. (2003). Etica e responsabilità d'impresa nelle relazioni internazionali. Symphonya-Emerging Issues in Management, 1.

Cater, E., \& Lowman, G. (1994). Ecotourism: A Sustainable Option? Chichester: John Wiley and Sons.

Cavuta, G. (2007). Territorio e cultura nella valorizzazione del paesaggio. Il caso di Santo Stefano di Sessanio. In Zarrilli, L. (Eds.), Lifescapes: Culture Paesaggi IdentitÀ (pp. 193-211). Milano: Franco Angeli.

Chen, Y. G., Chen, Z. H., Ho, J. C., \& Lee, C. S. (2009). In-depth tourism's influences on service innovation. International Journal of Culture, Tourism and Hospitality Research, 3(4), 326-336. http://dx.doi.org/10.1108/17506180910994541

Coda, V. (1985). Valori imprenditoriali e successo dell'impresa. Finanza, Marketing E Produzione, 2.

Colley Jr, J. L., Doyle, G. L., Logan, G. W., \& Stettinius, W. (2005). What is Corporate Governance? New York: McGraw Hill.

Confalonieri, M. (2008). Il turismo sostenibile. Turin: Giappichelli.

Confalonieri, M. (2011). L'albergo diffuso: una "formula" tutta italiana. Economia E Diritto Del Terziario, 2, 265-281.

D’Alessio, R. (2008). Le coalizioni aziendali. Caratteri del fenomeno e forme relazionali. Turin: Giappichelli.

Dall'Ara, G. (2010). Manuale dell'Albergo Diffuso-L'idea, la gestione, il marketing dell'ospitalità diffusa. Milan: Franco Angeli.

Dall'Ara, G., \& Esposto, M. (2005). Il fenomeno degli alberghi diffusi in Italia. Campobasso: Palladino.

Dropulić, M., Krajnović, A., \& Ružić, P. (2008). Albergo diffuso hotels-A solution to sustainable development of tourism. In 27th International Conference on Organizational Science Development-Knowledge for sustainable development, Portorož, Slovenia.

Edmondson, A. C., \& McManus, S. E. (2007). Methodological Fit in Management Field Research. Academy of Management Review, 32(4), 1155-1179. http://dx.doi.org/10.5465/AMR.2007.26586086

Eisenhardt, K. M. (1989). Building Theories from Case Study Research. Academy of Management Review, 14(4), 532-550.

Epifani, S. (2003). Business community: Gestire il Capitale Intellettuale nella net economy. Milan: Franco Angeli.

Fiorello, A., \& Bo, D. (2012). Community-Based Ecotourism to Meet the New Tourist's Expectations: An Exploratory Study. Journal of Hospitality Marketing \& Management, 21(7), 758-778. http://dx.doi.org/10.1080/19368623.2012.624293

Flagestad, A., \& Hope, C. A. (2001). Strategic success in winter sports destinations: a sustainable value creation perspective. Tourism Management, 22(5), 445-461. http://dx.doi.org/10.1016/S0261-5177(01)00010-3 
Flamholtz, E. G. (1986). How to make the transition from an entrepreneurship to a professionally managed firm. San Francisco: Jossey-Bass Publishers.

Flamholtz, E. G. (1989). Human Resource Accounting (2nd ed.). San Francisco: Jossey-Bass Publishers.

Franch, M. (2010). Marketing delle destinazioni turistiche. Metodi, approcci e strumenti. Milan: McGraw-Hill.

Franch, M., Martini, U., \& Della Lucia, M. (2011). La sostenibilità dello sviluppo turistico: il caso delle Dolomiti patrimonio naturale dell'Unesco. Impresa Progetto, 2, 1-8.

Fukuyama, F. (1995). Trust. New York: Free Press.

Giaccari, F. (2003). Le aggregazioni aziendali. Bari: Cacucci.

Giannoni, S. (2009). Tourism, growth and residents' welfare with pollution. International Journal of Culture, Tourism and Hospitality Research, 9(1), 50-60. http://dx.doi.org/10.1057/thr.2008.43

Godfrey, K., \& Clark, J. (2002). Manuale di marketing territoriale per il turismo. Florence: Le Monnier.

Gollin, M. A. (2008). Driving Innovation. Intellectual Property Strategies for a Dynamic World. New York: Cambridge University Press. http://dx.doi.org/10.1017/CBO9780511805394

Grandori, A. (1995). L'organizzazione delle attività economiche. Bologna: Il Mulino.

Grossman, S. J., \& Hart, O. D. (1988). One share-one vote and the market for corporate control. Journal of Financial Economics, 20(1), 175-202. http://dx.doi.org/10.1016/0304-405X(88)90044-X

Grzinic, J., \& Saftic, D. (2012). Approach To The Development Of Destination Management In Croatian Tourism. Management: Journal of Contemporary Management Issues, 17(1), 59-74.

Guatri, L. (1991). La teoria della creazione di valore. Milan: Egea.

Gulati, R. (1998). Alliances and networks. Strategic Management Journal, 19(4), 293-317. http://dx.doi.org/10.1002/(SICI)1097-0266(199804)19:4<293::AID-SMJ982>3.0.CO;2-M

Håkansson, H., \& Snehota, I. (1995). Developing Relationships in Business Networks. London: Routledge.

Himmelman, A. T. (2001). On coalitions and the transformation of power relations: collaborative betterment and collaborative empowerment. American Journal of Community Psychology, 29(2), 277-284. http://dx.doi.org/10.1023/A:1010334831330

Ho, P. T. (2011). An Empirical Study of Residents' Attitudes to Tourism Impact Management Strategies. Journal of American Academy of Business, 17(1), 232-238.

Holcomb, J. L., Upchurch, R. S., \& Okumus, F. (2007). Corporate social responsibility: What are top hotel companies reporting? International Journal of Contemporary Hospitality Management, 19(6), 461-475. http://dx.doi.org/10.1108/09596110710775129

Hussein Alhroot, A. H. (2012). An Evaluation of Social Marketing in Humanitarian Tourism Requirements by Using Social Networking Sites. International Journal of Marketing Studies, 4(4), 130-137.

Jamrozy, U. (2007). Marketing of tourism: a paradigm shift toward sustainability. International Journal of Culture, Tourism and Hospitality Research, 1(2), 117-130. http://dx.doi.org/10.1108/17506180710751669

Jensen, M. C., \& Meckling, W. H. (1976). Theory of the Firm: Managerial Behavior, Agency Costs and Ownership Structure. Journal of Financial Economics, 3(4), 305-360. http://dx.doi.org/10.1016/0304-405X(76)90026-X

Keller, P., \& Bieger, T. (2008). Real estate and destination development in tourism. Successful strategies and instruments. Berlin: ESV.

Kennett Hensel, P. A., Sneath, J. Z., \& Hensel, P. J. (2010). Developing sustainable tourism: managers' assessment of Jamaica's ten-year master plan. International Journal of Culture, Tourism and Hospitality Research, 4(2), 143-155. http://dx.doi.org/10.1108/17506181011045217

Kogut, B. (2000). The network as knowledge: Generative rules and the emergence of structure. Strategic Management Journal, 405-425. http://dx.doi.org/10.1002/(SICI)1097-0266(200003)21:3<405::AID-SMJ103>3.0.CO;2-5

Kokash, H. A. (2012). Jordanian Travel Agencies' Websites Assessment: Experts vs Tourists' Perceptions. International Journal of Marketing Studies, 4(2), 80-92. http://dx.doi.org/10.5539/ijms.v4n2p80

Lacchini, M. (2002). Corporate governance e bilanci d'impresa nella prospettiva della riforma. Turin: 
Giappichelli.

Lacchini, M., \& Trequattrini, R. (2012). La governance delle società di calcio professionistiche. Naples: Edizioni Scientifiche Italiane.

Lee, M. Y., Fairhurst, A., \& Wesley, S. (2009). Corporate Social Responsibility: A Review of the Top 100 US Retailers. Corporate Reputation Review, 12(2), 140-158. http://dx.doi.org/10.1057/crr.2009.10

Lev, B., \& Schwartz, A. (1971). L'applicazione del concetto di capitale umano nelle situazioni di bilancio. Sviluppo e Organizzazione, 8.

Levanti, G. (2010). Il governo dei sistemi reticolari di imprese. Milano: Franco Angeli.

Lomi, A. (1991). Reti organizzative. Teoria, tecnica e applicazioni. Bologna: Il Mulino.

Luhmann, N. (2002). La fiducia. Bologna: Il Mulino.

Maggioni, V., Potito, L., \& Viganò, R. (2009). Corporate Governance: governance, controllo e struttura finanziaria. Bologna: Il Mulino.

Mandelli, A., \& La Rocca, A. (2006). Networks in the management of heritage tourism: the case of "distributed hospitality" (albergo diffuso) in Italy. In The annual meeting of the International Communication Association, Dresden, Germany.

Martin, D., \& Woodside, A. G. (2008). Grounded Theory of International Tourism Behavior. Journal of Travel \& Tourism Marketing, 24(4), 245-258. http://dx.doi.org/10.1080/10548400802156695

Martini, U. (2005). Management dei sistemi territoriali. Gestione e marketing delle destinazioni turistiche. Turin: Giappichelli.

Matacena, A. (1984). Impresa e ambiente. Il bilancio sociale. Bologna: Clueb.

Mazanec, J. A., Wöber, K., \& Zins, A. H. (2007). Tourism Destination Competitiveness: From Definition to Explanation? Journal of Travel Research, 46(1), 86-95. http://dx.doi.org/10.1177/0047287507302389

Minguzzi, A., \& Presenza, A. (2010). Destination building. Teorie e pratiche per il management della destinazione turistica. Milan: Pearson.

Mohajerani, P., \& Miremadi, A. (2012). Customer Satisfaction Modeling in Hotel Industry: A Case Study of Kish Island in Iran. International Journal of Marketing Studies, 4(3), 134-152. http://dx.doi.org/10.5539/ijms.v4n3p134

Morita, M., James Flynn, E. E., \& Ochiai, S. (2011). Strategic management cycle: The underlying process building aligned linkage among operations practices. International Journal of Production Economics, 133(2), 530-540. http://dx.doi.org/10.1016/j.jpe.2010.09.003

Moscardo, G. (2008). Sustainable tourism innovation: Challenging basic assumptions. International Journal of Culture, Tourism and Hospitality Research, 8(1), 4-13. http://dx.doi.org/10.1057/thr.2008.7

Nicely, A., \& Palakurthi, R. (2012). Navigating through tourism options: an island perspective. International Journal of Culture, Tourism and Hospitality Research, 6(2), 133-144. http://dx.doi.org/10.1108/17506181211233063

Normann, R., \& Ramirez, R. (1995). Le strategie interattive. Dalla catena alla costellazione del valore. Milan: Etas.

Paniccia, P. (2011). Coevoluzione impresa turistica-ambiente e innovazione: il contributo dei fattori tempo e conoscenza. Turismo e psicologia, 77-104.

Paniccia, P. (2012). Nuovi fermenti di sviluppo sostenibile nel turismo: l'esempio dell'“albergo diffuso". Tra borghi storici, residenze d'epoca e antichi casali rurali. Impresa Progetto, 1, 1-26.

Paniccia, P., Minguzzi, A., \& Valeri, M. (2011). Coevoluzione tra impresa e destinazione turistica: l'esperienza innovativa dell'albergo diffuso. In Pilotti, L. (Eds.), Creatività, innovazione e territorio: ecosistemi del valore per la competizione globale (pp. 405-463). Bologna: Il Mulino,.

Paniccia, P., Pechlaner, H., \& Valeri, M. (2007). Da borgo ad albergo. Il caso Sextantio. La Rivista del Turismo, 4.

Paniccia, P., Pechlaner, H., \& Valeri, M. (2010). The Importance of the Time of Experience in the Innovation of Tourism Business. The Sextantio Albergo Diffuso. In Weiermair, K., Go, F., Keller, P., \& Pechlaner, H. (Eds.), Entrepreneurship and Innovation in Tourism. Berlin: Erich Schmidt Verlag. 
Paniccia, P., Silvestrelli, P., \& Valeri, M. (2010). Economia e management delle attività turistiche e culturali. Destinazione, Impresa, Esperienza. Contributi diricerca. Turin: Giappichelli.

Pechlaner, H., Paniccia, P., Valeri, M., \& Raich, F. (2012). Destination Governance. Teoria ed esperienze. Turin: Giappichelli.

Pechlaner, H., Pichler, S., \& Volgger, M. (2012). Dal Destination management alla destination governance: prospettive di gestione di destinazioni community e corporate based. In Pechlaner, H., Paniccia, P., Valeri, M., \& Raich, F. (Eds.), Destination Governance. Teoria ed esperienze. Turin: Giappichelli.

Pechlaner, H., Reuter, C., \& Bachinger, M. (2010). The Change Corridor in Transition from Region to Destination-The Case of the Franconian Lake District. In Keller, P., \& Bieger, T. (Eds.), Managing Change in Tourism Creating Opportunities-Overcoming Obstacles (pp. 67-86). Berlin: Erich Schmidt Verlag GmbH \& Co.

Pencarelli, T., \& Migliaccio, M. (2011). Creatività e innovazione nel turismo. In Pilotti, L. (Eds.), Creatività, innovazione e territorio: ecosistemi del valore per la competizione globale. Bologna: Il Mulino.

Pencarelli, T., \& Splendiani, S. (2010). Il governo sostenibile delle destinazioni turistiche. In Pencarelli, T. (Eds.), Marketing e Management del Turismo. Trieste: Edizioni Goliardiche.

Pencarelli, T., \& Splendiani, T. (2008). La gestione delle destinazioni dei prodotti turistici. Mercati $e$ competitività, 2.

Perkins, H. E., \& Brown, P. R. (2012). Environmental Values and the So-Called True Ecotourist. Journal of Travel Research, 51(6), 793-803. http://dx.doi.org/10.1177/0047287512451133

Pine, B. J., \& Gilmore, J. H. (1999). The Experience Economy. Boston: Harvard Business School.

Porter, M. E. (1998). Clusters and the New Economics of Competition. Harvard Business Review, 76, 77-90.

Resciniti, R. (2004). Il marketing orientato all'esperienza. L'intrattenimento nella relazione con il consumatore. Naples: Edizioni Scientifiche Italiane.

Resciniti, R., \& Maggiore, G. (2009). Event experience. Progettare e gestire eventi da ricordare. Naples: Edizioni Scientifiche Italiane.

Ricciardi, A. (2010). Strategie di cooperazione tra aziende e mitigazione del rischio operativo: i vantaggi competitivi delle reti di imprese. In Airoldi, G., Brunetti, G., Corbetta, G., \& Invernizzi, G. (eds.), Scritti in onore di Vittorio Coda. Milan: Egea.

Rispoli, M., \& Brunetti, G. (2009). Economia e management delle aziende di produzione culturale. Bologna: Il Mulino.

Rispoli, M., \& Tamma, M. (1996). Le imprese alberghiere nell'industria dei viaggi e del turismo. Padova: Cedam.

Ritchie, J. R. B, \& Crouch, G. I. (2000). The competitive destination: A sustainability perspective. Tourism Management, 21, 1-7.

Rullani, E. (1993). La conoscenza e le reti. Sinergie, 31.

Rullani, E., Paiola, M., Sebastiani, R., Cantù, C., \& Montagnini, F. (2007). Innovare che passione. Quaranta modi di essere creativi nel business dei servizi. Milan: Franco Angeli.

Ruozi, R. (2005). Sostenibilità e competitività del settore turistico. Economia \& Management, 2, 95-99.

Saayman, M., Rossouw, R., \& Saayman, A. (2012). Does conservation make sense to local communities? Development Southern Africa, 29(4), 588-609. http://dx.doi.org/10.1080/0376835X.2012.715444

Saraithong, W., \& Chancharoenchai, K. (2011). Tourists' Behaviour in Thai Homestay Business. International Journal of Management Cases, 13(3), 112-126.

Schillaci, C. E., \& Gatti, C. (2011). E pluribus unum: intenzionalità collettiva e governo dei sistemi territoriali. Sinergie, 84, 21-45.

Schillaci, C. E., \& Longo, M. C. (2010). Territori Imprenditoriali. Nuovi scenari di competitività etica. Soveria Mannelli: Rubettino.

Sciarelli, S. (2007). Etica e responsabilità sociale nell'impresa. Milan: Giuffrè.

Sheikh, S., \& Chatterjee, S. K. (1995). Perspective on Corporate Governance. In Sheikh, S. (ed.), Corporate 
Governance \& Corporate Control. London: Cavendish Publishing Limited.

Shikida, A., Yoda, M., Kino, A., \& Morishige, M. (2010). Tourism relationship model and intermediary for sustainable tourism management: Case study of the Kiritappu Wetland Trust in Hamanaka, Hokkaido. Tourism and Hospitality Research, 10(2), 105-115. http://dx.doi.org/10.1057/thr.2009.29

Silvestrelli, P. (2011). Valorizzazione del patrimonio culturale e sviluppo dell'“albergo diffuso": interdipendenze e sinergie. Journal of the Department of Cultural Heritage, 2, 253-274.

Taleghani, M., Sharifi, A. S., \& Mousavian, S. J. (2011). Tourism Management as an Economic Development Tool in Iran. International Journal of Business Administration, 2(4), 69-74. http://dx.doi.org/10.5430/ijba.v2n4p69

Tasci, D. A., \& Boylu, Y. (2010). Cultural Comparison of Tourists' Safety Perception in Relation to Trip Satisfaction. International Journal of Tourism Research, 12, 116-133.

Tidd, J., Bessant, J., \& Pavitt, K. (1997). Managing innovation. Integrating technological, market and organizational change. New York: John Wiley \& Sons.

Tonini, N. (2010). Etica e turismo, La sfida possibile. Turin: Edizioni San Paolo.

Trequattrini, R. (1999). Economia aziendale e nuovi modelli di corporate governance: esperienze a confronto. Turin: Giappichelli.

Trequattrini, R., Recinto, G., \& Russo, G. (2012). Innovation and Company Networks. Quaderni della Rivista Impresa Ambiente Management, 3.

Trequattrini, R., Russo, G., \& Lombardi, R. (2012a). Network Governance: Organizational and Legal Profiles. Corporate Ownership \& Control, 9(4).

Trequattrini, R., Russo, G., \& Lombardi, R. (2012b). Defining Business Network. International Journal of Business Research and Management, 3(1).

Trunfio, M. (2008). Governance turistica e sistemi turistici locali. Modelli teorici ed evidenze empiriche in Italia. Turin: Giappichelli.

Turco, M. (2004). L'incidenza del patrimonio intellettuale sullo sviluppo aziendale. Modelli di analisi. Bari: Cacucci.

Valeri, M. (2011). The Role of Time for the Competitiveness of SMEs in the Service Sector. Department of Business Studies (DSI) Essays Series, 17.

Varanini, F. (2011). Sostenibilità. Sinergie, 85.

Weaver, D. B. (2000). A broad context model of destination development scenarios. Tourism Management, 21(3), 217-224. http://dx.doi.org/10.1016/S0261-5177(99)00054-0

World Commission on Environment and Development. (1987). Our Common Future. Oslo.

Yin, R. K. (2009). Case Study Research: Design and Methods (4th ed.). Thousand Oaks-California: Sage Publications.

Zanda, G. (2009). Il governo della grande impresa nella società della conoscenza. Turin: Giappichelli.

Zanda, G., Lacchini, M., \& Oricchio, G. (1993). La valutazione del capitale umano dell'impresa. Modelli qualitativi e quantitativi di logica economico-aziendale. Turin: Giappichelli.

Zanelli, E. (1997). Corporate Governance: ricerche e spunti per il confronto. Rivista dell'Ordine dei Dottori Commercialisti di Roma, 47.

Zeppel, H. (2010). Managing cultural values in sustainable tourism: Conflicts in protected areas. Tourism and Hospitality Research, suppl, 10(2), 93-104. http://dx.doi.org/10.1057/thr.2009.28 